III Nordisk Ministerråd
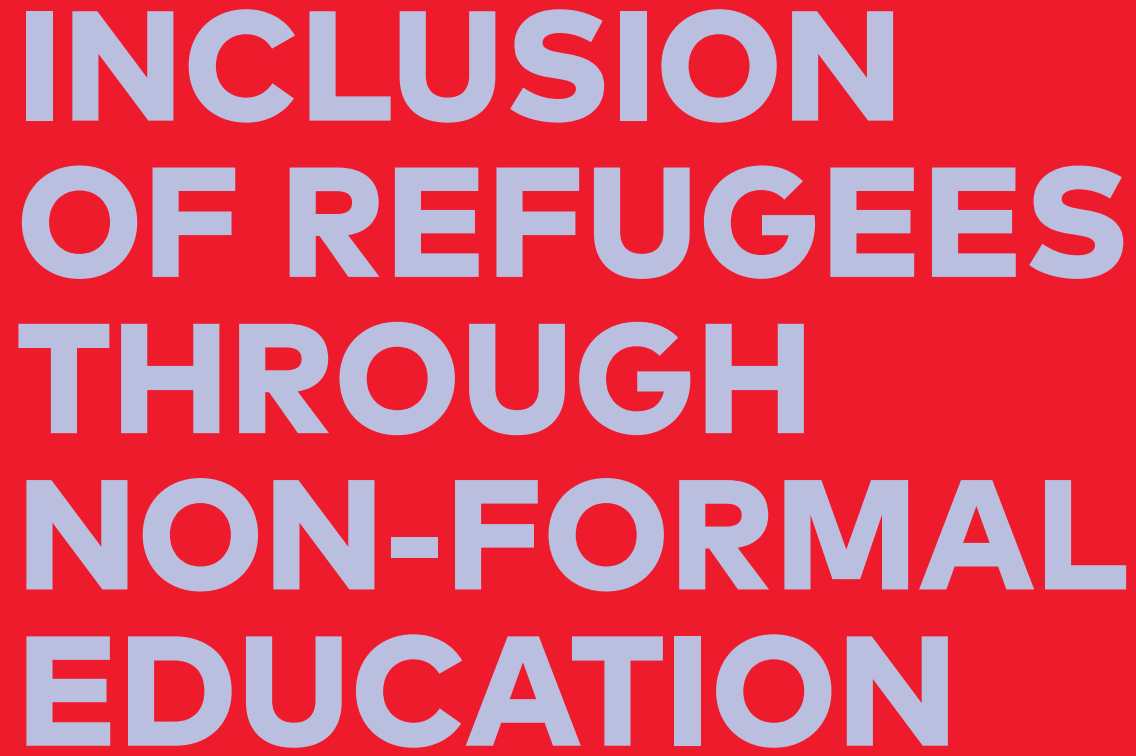

2017

- NORDIC BEST PRACTICE 



\section{Inclusion of refugees through non-formal education 2017}

- Nordic best practice

Kajsa Wiktorin

TemaNord 2017:552 
Inclusion of refugees through non-formal education 2017

- Nordic best practice

Kajsa Wiktorin

ISBN 978-92-893-5150-8 (PRINT)

ISBN 978-92-893-5151-5 (PDF)

ISBN 978-92-893-5152-2 (EPUB)

http://dx.doi.org/10.6027/TN2017-552

TemaNord 2017:552

ISSN 0908-6692

Standard: PDF/UA-1

ISO 14289-1

(c) Nordic Council of Ministers 2017

Print: Rosendahls

Printed in Denmark

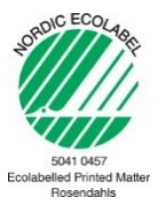

\section{Disclaimer}

This publication was funded by the Nordic Council of Ministers. However, the content does not necessarily reflect the Nordic Council of Ministers' views, opinions, attitudes or recommendations.

\section{Rights and permissions}

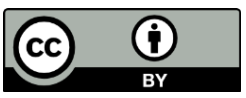

This work is made available under the Creative Commons Attribution 4.0 International license (CC BY 4.0) https://creativecommons.org/licenses/by/4.o.

Translations: If you translate this work, please include the following disclaimer: This translation was not produced by the Nordic Council of Ministers and should not be construed as official. The Nordic Council of Ministers cannot be held responsible for the translation or any errors in it.

Adaptations: If you adapt this work, please include the following disclaimer along with the attribution: This is an adaptation of an original work by the Nordic Council of Ministers. Responsibility for the views and opinions expressed in the adaptation rests solely with its author(s). The views and opinions in this adaptation have not been approved by the Nordic Council of Ministers. 
Third-party content: The Nordic Council of Ministers does not necessarily own every single part of this work. The Nordic Council of Ministers cannot, therefore, guarantee that the reuse of third-party content does not infringe the copyright of the third party. If you wish to reuse any third-party content, you bear the risks associated with any such rights violations. You are responsible for determining whether there is a need to obtain permission for the use of third-party content, and if so, for obtaining the relevant permission from the copyright holder. Examples of third-party content may include, but are not limited to, tables, figures or images.

Photo rights (further permission required for reuse)

Any queries regarding rights and licences should be addressed to:

Nordic Council of Ministers/Publication Unit

Ved Stranden 18

DK-1061 Copenhagen $\mathrm{K}$

Denmark

Phone +4533960200

pub@norden.org

\title{
Nordic co-operation
}

Nordic co-operation is one of the world's most extensive forms of regional collaboration, involving Denmark, Finland, Iceland, Norway, Sweden, and the Faroe Islands, Greenland and Åland.

Nordic co-operation has firm traditions in politics, economics and culture and plays an important role in European and international forums. The Nordic community strives for a strong Nordic Region in a strong Europe.

Nordic co-operation promotes regional interests and values in a global world. The values shared by the Nordic countries help make the region one of the most innovative and competitive in the world.

\author{
The Nordic Council of Ministers \\ Nordens Hus \\ Ved Stranden 18 \\ DK-1061 Copenhagen K, Denmark \\ Tel.: +4533960200 www.norden.org \\ Download Nordic publications at www.norden.org/nordpub
}





\section{Contents}

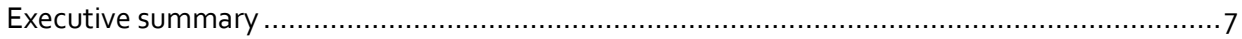

1. An increase of newly arrived immigrants in the Nordic countries................................ 9

2. Presentation of the result and discussions on successful models for inclusion.................... 11

2.1 Summary of researchers' conclusions......................................................... 11

2.2 Henrik Nordvall and Eva-Marie Harlin, Linköpings universitet, Sweden ..................13

2.3 Sissel Kondrup, Uddannelses forbundet, Copenhagen, Denmark ..........................14

2.4 Jorun M. Stenøien and Christin Tønseth, Institutt for pedagogic og livslang laering,

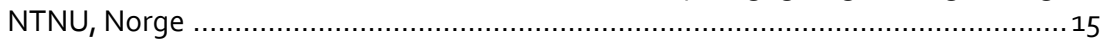

2.5 Andreas Fejes, Linköpings universitet ...................................................... 15

3. Round-Table discussion, a different perspective ................................................. 17

4. Non-formal education has the ability of seeing the whole person...................................19

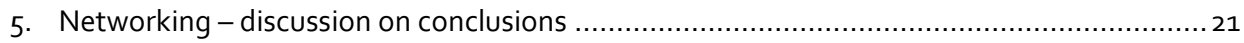

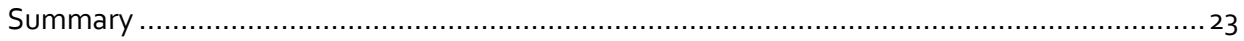

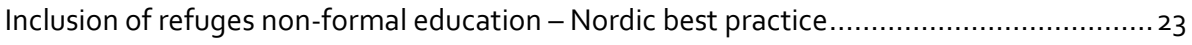

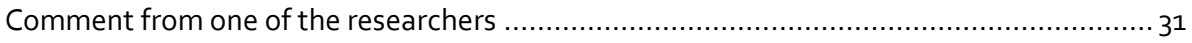

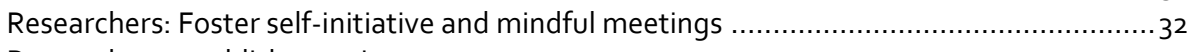

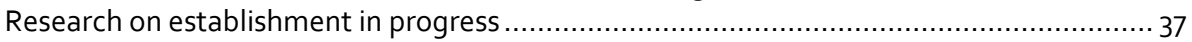

Interview with David Samuelsson - New meetings and Nordic perspectives on

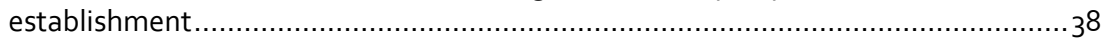

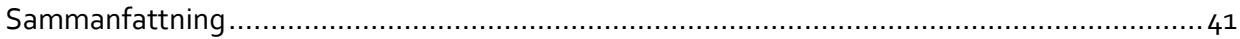

Inkludering av nyanlända genom det icke-formella lärandet -Nordiska goda exempel .......41

Appendix 1. Participating researchers in the project....................................................43

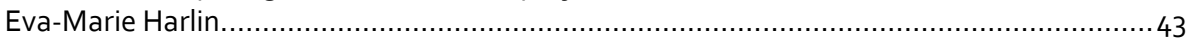

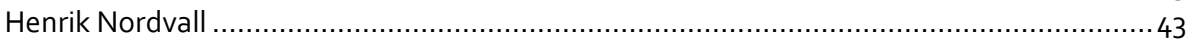

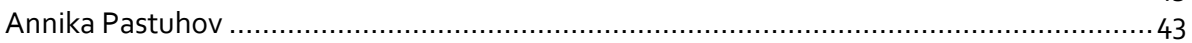

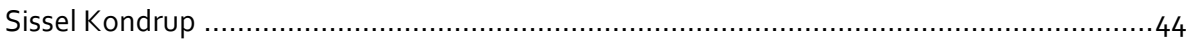

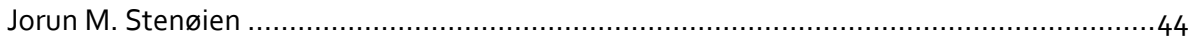

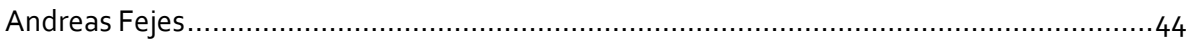

Appendix 2. Participating projects in the study ….................................................. 45

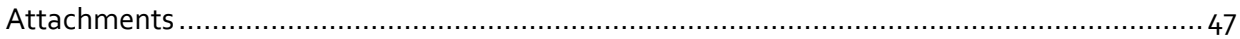





\section{Executive summary}

During 2016 and 2017, Studieförbunden in Sweden (the umbrella organization for the ten study associations in Sweden), together with their Nordic sister organizations Folkbildning Norden - ran the project People's education and adult education sector's role in integration.

The project aimed at giving a picture of the various Nordic models for inclusion of newly arrived immigrants. Twenty-two selected examples of activities were gathered from non-formal educators and civil society groups in the Nordic countries and handed over to a research group. Five good activity examples each from Denmark, Finland, Norway and Sweden and two examples from Iceland are included in the study. The research work was carried out by five researchers or researchers in pairs from the Nordic countries, and led by MIMER, with national responsibility for research on non-formal education in Sweden. The researchers have mainly looked at factors that affect newly arrived immigrants' possibilities for employment. In addition, parameters such as understanding of the new society and language skills were also included. Non-formal education in this context is related to the concepts of recurrent and lifelong learning which often takes place outside recognized educational institutions.

The project presented it's result during a one day program at the NCAEL 7th Nordic Conference on Adult Education and Learning, 3-5 May 2017 in Jönköping in Sweden, where researcher, experts and practitioners from the Nordic countries discussed and formulated ten conclusions of best models for inclusion.

What is required for new arrivals to become part of a new society and working life? This was the questions of the project and the questions to answer during the conference.

This report describes all parts of the project. The ten conclusions on good inclusion based on Nordic activates are attached as well as documents for disseminating, to start discussions and increase the knowledge about models for inclusion of new arrivals. 



\section{An increase of newly arrived immigrants in the Nordic countries}

The world has seen an increase of $50 \%$ of migration since 1990. In the Nordic countries, the number has doubled. In 2016, approximately 26.7 million people lived in the Nordic countries. Since 1990, the foreign-born population has increased from 1.3 million to 3.0 million.

In the past, it was common for people to move within the Nordic countries. When the EU expanded in the early 2000s, many emigrated from new membering countries, especially Poland. More recently, Syrians, Iraqis, Eritreans and Afghans have made up most of the newly arrived immigrants in the Nordic countries. The foreign born population is young. The $25-35$ age group accounts for a larger proportion than the native population of each cohort. The fact that they are young can also mean that there is a greater chance of taking part in the workforce, lowering the median age in the Nordic countries.

Considerable changes in population involve both great opportunities and challenges. Different values, norms, structures and cultures meet and have to find their way together. New knowledge and other experiences should be included in the workforce. Therefore, it is important to be open for change and see the opportunities at hand. Models that include and utilize new inhabitants have evolved, and they must be evaluated and further developed to create the new conditions needed in an everchanging world.

The organisations of non-formal education in the Nordic countries have deep experience in developing activities for newly arrived immigrants. When major societal changes occur, non-formal education can act quickly and meet people's needs in their context. During 2016 and 2017, Studieförbunden in Sweden (the umbrella organization for the ten study associations in Sweden), together with sister 
organizations in the Nordic countries (Folkbildning Norden), ran the project People's education and adult education sector's role in integration and employment efforts in the Nordic region. The project aimed at giving a picture of the various Nordic models for the inclusion of newly arrived immigrants. This project was carried out with the support of The Nordic Council of Ministers and in cooperation with NVL (Nordic Network for Adult Learning).

Twenty-two selected examples of activities were gathered from non-formal educators and civil society groups in the Nordic countries and handed over to a research group. Five good examples each from Denmark, Finland, Norway and Sweden and two examples from Iceland are included in the study. Each example spans a wide variety of activities, from hiking trips in the Norwegian mountains for young newcomers and citizen association understanding for Muslim women who would like to participate in Swedish citizen associations, to education for newly arrived immigrants in Finland who need to upgrade their skills and quickly move into the workforce. The research work was carried out by five researchers or researchers in pairs from the Nordic countries, and led by MIMER, with national responsibility for research on non-formal education in Sweden. The researchers have mainly looked at factors that affect newly arrived immigrants' possibilities for employment. In addition, parameters such as understanding of the new society and language skills were also included.

Non-formal education in this context is related to the comcepts of recurrent and lifelong learning which often takes place outside recognized educational institutions. Formal education is normally the term for education delivered by trained teachers in a systematic international way within a school, higher education or university. 


\section{Presentation of the result and discussions on successful models for inclusion}

The research of the twenty-two examples was conducted in the winter of 2016-2017. The results were presented on 4 May 2017 during a day-long program at NCAEL 7th Nordic Conference on Adult Education and Learning in Jönköping.

In addition to a research symposium, the day-long program consisted of a RoundTable discussion with a cross-sector perspective as well as a part on networking. During the last part of the conference, the participants, who consisted of researchers, practitioners and experts, were asked to identify and formulate the conditions necessary for the successful inclusion of newly arrived immigrants in the workforce and in society. David Samuelsson, Secretary- General of Studieförbunden in Sverige, was the chairman of the first sessions and the part on networking was facilitated by Peter Wiborn.

\subsection{Summary of researchers' conclusions}

\subsubsection{Annika Pastuhov, Åbo Akademi, Finland}

Some central ideas of popular education, such as voluntary participation and a starting point in the needs and interests of the participants, serve a central purpose in several descriptions. At the same time these ideas are sometimes combined with compulsory integration education, abandoning the idea of voluntary participation as a corner stone of popular education. This is something that some writers also point out. This is a balancing act between serving target groups that are considered to be important for popular education, and the aims and goals set out by the state 
specifically when it comes to integration. A noteworthy goal, prescribed by the states, is that of fast entrance into the labour market.

Here, in the material analysed above, immigrants are thought to be in need of language skills, professional skills, and general norms and values. However, there is not much mention of the importance of providing opportunities to also maintain a cultural heritage, something that previous research has pointed out as a characteristic part of the interplay between popular education organisations and immigrants (Osman, 2013). It is also noteworthy that not much attention is paid to the creation of arenas for dialogue (ibid.).

When it comes to another ideal for popular education, the democratic coproduction of knowledge, popular educators in some cases state that they, too, are learning from the participants. Still, the major view on the knowledge for integration seems to be that of a transfer of knowledge from the natives to the "Others" (Osman, 2013), not explicitly drawing on the knowledge of the (immigrant) participants.

The data material leaves many questions unanswered. This is partly due to the nature of the data, but also to a large part because of the tentative and inconclusive analysis in this paper. In many cases in the material, it is difficult to perceive what is actually done to achieve certain goals or to realize certain actions. The context is also blurred and a thorough reading of the material would need a better understanding of the different contexts.

The material raises questions about the meaningfulness of separating popular education and formal vocational education. At least these descriptions of integration practices make an interesting case where a lot of "good examples" of popular education are quite closely linked to the formal education systems of the country in question. Of course a vocation and jobs are important for all and constitute important political goals for the entire population. Still, it seems that basic education is considered to be different for the population born in the country versus the newcomers.

Are here two different notions of citizenship in popular education at play here? One is mainly for the natives, for whom popular education is about voluntary leisure activities and meaningful learning as a contrast to everyday life. The other citizenship is for the immigrants, the outsiders; the ones who are lacking something essential and are in need of being included in society, thus making popular education in some cases even compulsory. 
Popular education is thought to channel the voices and needs of its participants. I have in this paper presented some doubts on this when it comes to integration practices. Further exploration on this issue would probably benefit from the voices of the participants.

\subsection{Henrik Nordvall and Eva-Marie Harlin, Linköpings universitet, Sweden}

It is essential to underscore the data presented in this paper does not allow us to make any conclusions about the effectiveness of the presented educational activities. Another, much more rigorous research designed would have been needed for any such claims. An elaborated conceptual framework would also have been needed, defining and operationalizing concepts such as "inclusion" and defining what "successful" means in this context. The data collected may give insight on how popular educators give reasons to and legitimatize their activities. It may also say something about the preferences and ideals among the organizers.

With empirical data from such a variety of activities, that these projects represent, it is problematic and not necessary to make any general conclusions.

What can be said, though, is that the purpose of all reported projects in some ways was to contribute to the inclusion of the newly arrived refugees in the country. The awareness of this rather unclear concept and the political aim related to it varies in the projects. Strategies to achieve this aim differ depending on both the target groups and on the one that organizes the activities. In most of the reported projects, however, the idea of Nordic popular education as a pedagogical vision and as a successful tool is very strong. Popular education ideas are thus constructed as compatible with quite different objectives, even with objectives that can be understood as a relatively instrumental versus establishment at the labour market. This differs from a common conception of popular education as referring to a more the free formation processes, beyond the labour market requirements. The desire for a best practice might exist among those working in these projects. However, as the answers to the didactic questions must be different in different contexts, a general and detailed recommendation for best practice is not possible. But perhaps can these 22 selected examples still represent good examples for others who are supposed to 
work with similar projects in the future; thus spreading the examples might point out a wider selection of possible didactic choices for educators working in similar contexts.

In this paper we have located some of the characteristics found in data and discussed it in relation to some aspects of didactic theories to understand the purposes of the educational activities. One important aspect, not dealt with here but something to consider in further research and discussion, is in what ways norms and values are mediated in the different projects. The choice of content and how it is presented always conveys an image of who the participants are supposed to be and how they are expected to act in the new society. Most certainly, the choice of the content in the different projects will to some extant affect those involved. Despite the explicit ambition of promoting inclusion, norms and social processes existing within popular education might very well also create patterns of exclusion and marginalization of newly arrived. Popular education does not rest solely on the idea of community, solidarity and the idea of emancipation and equality. As indicated in studies by for example Osman (1999; 2013 and Dahlstedt et al (2016) it also entails patterns of marginalization and processes of "othering" in relation to people with immigrant background. 13 It would thus be relevant to ask in what ways it can be said that the reported projects helped the participants to get the opportunity not only to embrace and become part of the values that prevail in their new country but also where offered opportunities to develop and be part of society on their own terms. However, how this is achieved cannot be answered on the basis of the data in this study and is an open question for further inquiry.

\subsection{Sissel Kondrup, Uddannelses forbundet, Copenhagen, Denmark}

In order to meet the challenges related to work place culture identified in the bus project, it seems like there is a need for a more explicit focus on how ethnic minorities/newcomers can be perceived as and position themselves as a resource in the workplace, enriching the work place culture. Furthermore, there is a need for reflections on when and why cultural and linguistic differences can result in misunderstandings and lead to conflicts, and how such misunderstandings can be avoided and handled. One way of doing this, could be by strengthening the 
cooperative reflections within the educational settings, by making the participants share their experiences and try to develop a common language and common action strategies.

\subsection{Jorun M. Stenøien and Christin Tønseth, Institutt for pedagogic og livslang laering, NTNU, Norge}

Through the examples described in this paper, we see that choosing a local context as opportunity-rooms for learning gives a wide range of relevant immediate wider outcomes. The purpose of using opportunity-rooms as a relevant medium for learning, is to use real life experiences as a pedagogic medium that also gives immigrants an opportunity to experience in an integrated social manner where meetings and sharing experiences is viewed as immediate outcomes.

According to a possibility-driven design, opportunity-rooms for learning was created in peoples' daily life activities or activities that contribute to the immigrants interests and affecting their well being, commitment, interest and interaction with others. We believe that possibilities in moments of engagement, interest and social meetings represent promising entry points to language learning, to the creation of social capital, for bridging and inclusion. More importantly, it provides an opportunity to apply their learning in future everyday life in Norway.

A question that we always should ask is to what degree does the immigrant become a recipient? How can immigrants knowledge and ways of doing become a resource to mirror the local knowledge and culture and increase a common social capital?

\subsection{Andreas Fejes, Linköpings universitet}

In this paper I have argued for the need for further research on the long-term effects of adult migrants participation in different langue learning practices in Sweden. More precisely, I have illustrated how previous research, as well as current evaluation of popular education initiatives for migrants, do not take into account the long-term effects of participation in such practices, nor taking "enough" account of participants own views on such participation. I have also argued that these kinds of interventions 
are problematic in that the migrant "other" is expected to adapt to current structures and discourses. Thus, other ways of being and behaving are excluded. This provide a double bind, i.e. with a focus on adaptation to current structures and discourses, in combination with the exclusion of migrants own views on the roles of specific initiatives (on the long run), ways of changing current discuses and structures might be made less possible or even less likely. This is highly problematic, and in need of further debate. 


\section{Round-Table discussion, a different perspective}

Following the research symposium, there was a Round-Table discussion where Inaluk Brandt and Antti Vientu participated and gave their perspective on activity examples and the researchers' results. Both are part of NVL's network "Entrepreneurship, Entrepreneurial Learning and Innovation".

Inaluk Brandt discussed the need for integration from both directions. All northerners, regardless of their place of birth, should review their self-image and consider how they can contribute and ask newly arrived immigrants what they themselves long for in their new country. Is it sure that what "we" want to teach is what's needed and what is right? Inclusion is a twoway street.

Antti Vuentto took a similar perspective when he spoke of the importance of seeing newcomers as valuable citizens of the new country and not as "struggling individuals." He also emphasized the importance of prompting a dialogue so we can learn about and understand each other's values. Dialogue must be prompted at all levels and involve individuals and organisations as well as the surrounding society and culture.

They both spoke of the importance of creating conditions or so-called "opportunity rooms", where both needs and dreams can be accommodated, developed and created. 



\section{Non-formal education has the ability of seeing the whole person}

The conference's theme was Adult Education in the Age of Global Mobility, where nonformal and formal education was in focus. Studieförbunden's conference program focused on non-formal education in the Nordic region and its activities for newly arrived immigrants.

When people coming to a new country they are expected to learn the language and eventually become part of the workforce and society, non-formal and formal education have different functions. Some people can go straight to the job market, while others have a longer way into society. Those who are young, lack education, have no experience in work-life or for other reasons have a long way to go before they can study or work, of course face other challenges than those with academic degrees and years of work experience.

Inaluk Brandt raised general differences between formal and non-formal education by dividing them in the following way.

It is clear that formal education suits those who are already part of an academic context, while non-formal education has the ability of seeing the person as a whole, taking into account and meeting individual needs. 


\section{Formal and non-formal 'education' (highly caricatured)}

- Focuses on the topic / obtain new knowledge

- Learning in classroom

- Predefined curriculum

- Teacher-role: expert to non-expert

- Test-all must 'gain' the same

- Validation - other knows what you have obtained

- Institutionalized

- Not visible for society

- Learning is the goal

- Not influenced by participants background history and knowledge
- Focuses on life skills, relation building networking, social capital etc.

- Learning can happen everywhere

- Flexible content

- Everybody learns / facilitated learning

Individual learning

- No validation - own experience of learning

Cooperate with local organizations and society

- Visible for society

- Problem solving / task driven (learning is a positive consequence)

- Influenced by participants background history and knowledge 


\section{Networking-discussion on conclusions}

During the networking section, a workshop was conducted where the conference participants were divided into groups, who at each table received a "tablecloth" claiming successful inclusion based on the twenty-two activity examples that were gathered. At each table, the claims were discussed and developed, and notes were taken on these tablecloths, which were collected after the exercise for compilation.

Figure 2: Tablecloth for discussions
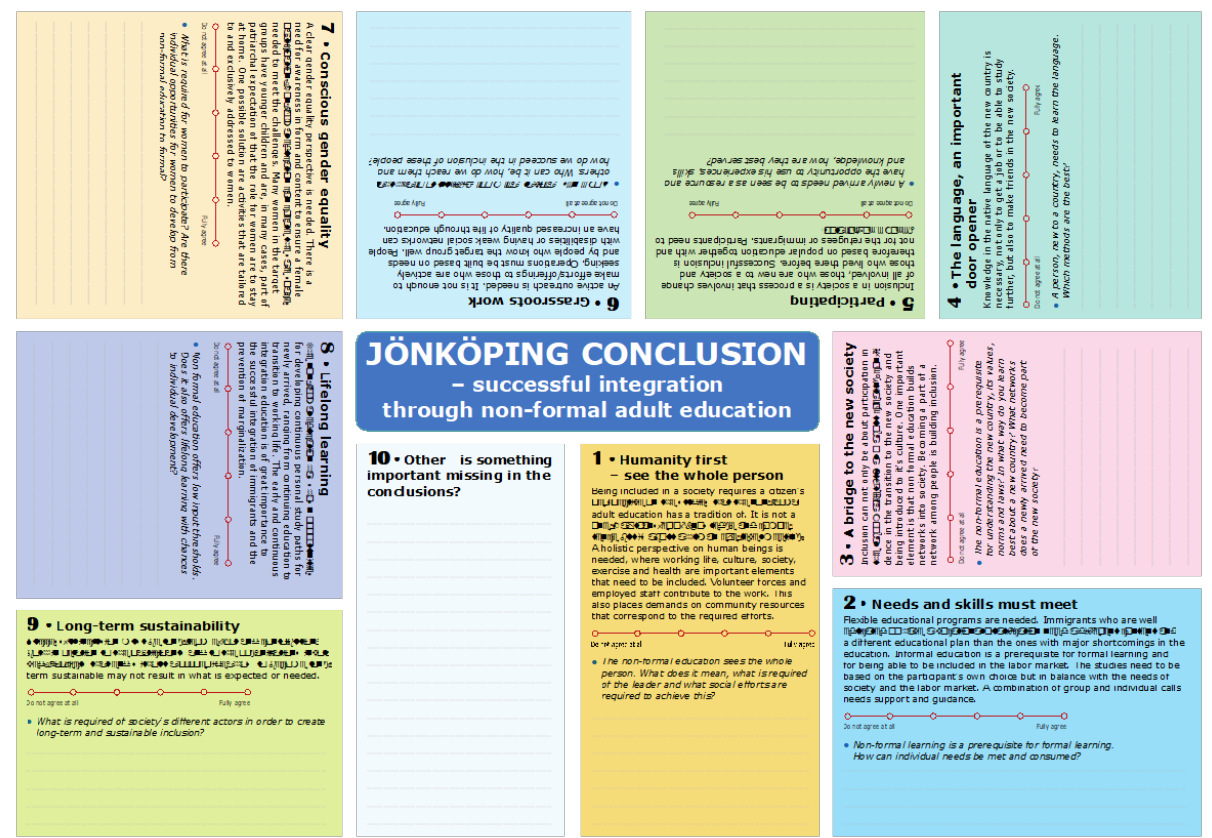

\section{JÖNKÖPING CONCLUSION \\ - successful integration \\ through non-formal adult education}

10 - other is something important missing in the condusions?
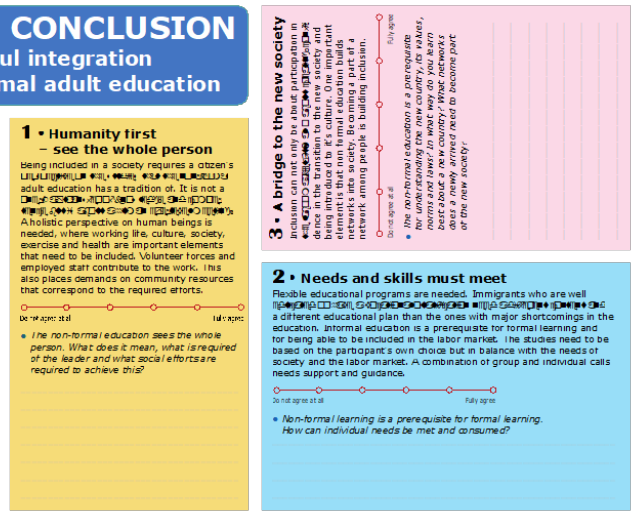
The comments gathered from the tablecloths were compiled to create ten conclusions for the successful inclusion of newly arrived immigrants in the labour market and in society as a whole. Based on these conclusions, existing and future models for inclusion can be inspired and developed, both in formal and non-formal education.

Figure 3: Participants on the conference

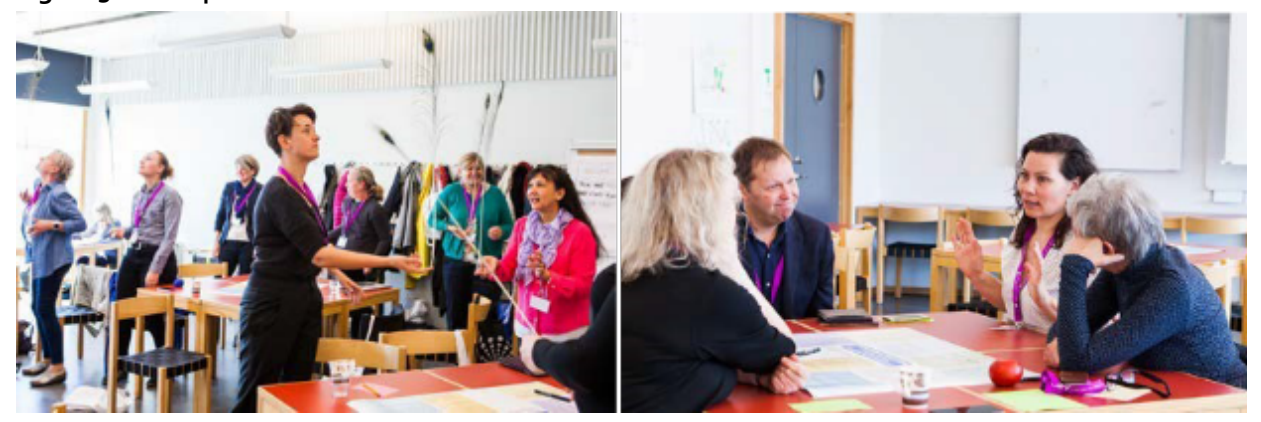




\section{Summary}

\section{Inclusion of refuges non-formal education - Nordic best practice}

Twentytwo selected examples of non-formal education's work on the inclusion of newly arrived immigrants and five research articles formed the basis for the day-long program at the NCAEL 7 th Nordic Conference on Adult Education and Learning. The final result, based on these findings, leads to the following conclusions on non-formal education's view on successful inclusion. Each conclusion has been linked to one or more researchers and comments based on the descriptions of various examples.

The research on non-formal education has been carried out by five researchers or researchers in pairs from the Nordic countries, and was led by MIMER, with national responsibility for research on non-formal education in Sweden. This project has been carried out with the support of the Nordic Council of Ministers and in collaboration with NVL, the Nordic Network for Adult Learning.

\section{Participation creates conditions for inclusion}

Non-formal education is based on the fact that inclusion is a process that involves participation from those who are new to a society and those who already belong to one. Newly arrived immigrants, like those who have lived in a country for a long time, must become co-creators, both of their own lives and of their new country. This is a prerequisite for the sustainability of inclusion. Non-formal education provides the conditions required to create this new reality together.

Successful inclusion is achieved with and not for newcomers and together with the already established population.

Participation gives people the opportunity to bring forth and demonstrate their full range of skills and capacities, which can then be used in the workforce and in society. People who meet and find each other within the context of non-formal education then have further occasions to continue networking and expanding 
opportunities. The emphasis of this approach in non-formal education is a key difference to formal education and leads to better results.

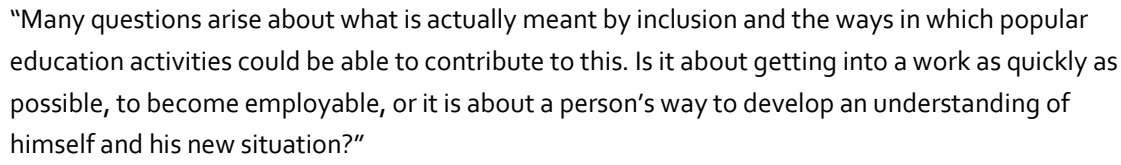

"Cases studies indicate positive effects in terms of self-confidence among participants, as well as indicating an increased interest for further learning as well as bringing migrants closer to the labour market."

Andreas Fejes, researcher

\section{The person as a whole must be included}

One of the basic values of non-formal education is that you must have a citizen's perspective on education in order to be included in society. It is not a one-sided transfer of knowledge and skills but more of a true meeting of equals where the meeting adopts a holistic perspective and includes topics such cultural and social life, exercise and health, in addition to work life. A holistic approach to people offers a broader perspective and a more comprehensive picture, opening up for various opportunities in the workforce and in society.

Too few newly arrived immigrants begin to work or study soon after their arrival. Non-formal education can quickly provide the social context needed for newcomers to land in their new reality and later create the necessary networks that can lead to better work and social life. Non-formal education would like to give the person as a whole space to create favourable conditions for the full spectrum of his or her capacities to flourish. An inclusion process can begin with learning about health, diet and physical exercise, all while working parallel with language proficiency leading to 
formal education and work. A narrowly directed education does not offer the same sustainable results.

"The varied and broad focus on work experience, culture, society and health is structured on the basis that a holistic approach can best take care of and help the individual."

FOKUS Flexpraktik - Daghøjskoleforeningen, Aalborg, Denmark

"The aim of the project was to give newly arrived adolescents a taste of outdoor life that permeates Norwegian culture. This can contribute to more learning and understanding through trying activities the youngsters have not tried before. These activities contribute to a more concrete form of integration into society by taking part in an important part of the Norwegian cultural heritage."

EMA prosjekt Den Norske Turistforening, Norway

\begin{abstract}
"Participating in an orchestra consists mainly of musical development in a social setting. Research shows that this contributes to a significantly increased quality of life. Participation in music activities can have a preventive and health-promoting effect for both children and adults as learning in partnership, among other things, fosters teamwork, sense of accomplishment, networking, belonging and identity.

The musical activity is the focal point and creates a sense of belonging. It is in itself including and is also a good arena for getting work experience."
\end{abstract}

WinterPULSE, Norway

\title{
3. Newly arrived immigrants have different backgrounds and hence different needs
}

Non-formal education represents a more flexible educational contact than traditional education. Those who are well educated or have professional qualifications can easier get into the workforce and need a different context and a different educational approach in comparison to those who have had poor education and may have a longer road ahead. Both formal and non-formal learning must be matched with the right individuals. Studies must be based on their own choices, while at the same time balancing with the needs of society and the job market. For successful and long-term inclusion, everyone should be given the opportunity for lifelong learning based on his or her own abilities. Therefore, a combination of group activities and individual support and guidance counselling is needed 
"An important aspect is also that students choose themselves and within their individual interests. The free choice of subjects and dedication strengthens the individual development in balance with the joint project. The balance between having subjects exclusively for students with refugee backgrounds and subjects for mixed groups also provides reciprocal activity that can help create a feeling of safety in the Danish subjects and the learning challenges that are created in the mixed groups, especially challenging the pupil's linguistic learning."

Silkeborg Højskole, Denmark

\title{
4. Language paves the way to employment, culture and society
}

Language proficiency is necessary not only to earn a living and for further education, but is also useful in meeting new people in a newsociety.

Earlier it was said that language comes first, then work. However, many decisionmakers are now talking about language skills being developed through work itself. But not all professions require language skills, and not all workplaces offer a context that promotes learning a language. Non-formal education would like to highlight language as a fundamental way into society, opening the doors to a new culture, not just focusing on the labour market. Inclusion requires a common language.

\footnotetext{
"At a time when the understanding of integration is sometimes reduced to participation in the labour market, this project also emphasizes introducing Danish working culture and creating confidence in the transition to Danish society."
}

Kursustrappen - Frederiksberg, Denmark

\begin{abstract}
"The most important factor for integration is considered to be sufficient knowledge of the Finnish language, which enables both progress in studies and employment. In addition to that, language proficiency also helps to find Finnish friends. Getting acquainted with Finnish culture and finding hobbies results in supporting integration."
\end{abstract}

Kiteen Evankelinen Kansanopisto, Finland

\begin{abstract}
"A balancing act between serving target groups that are considered to be important for popular education, and the aims and goals set out by the state specifically when it comes to integration. A noteworthy goal, prescribed by the states, is that of fast entrance into the labour market."
\end{abstract}

Annika Pastuhov, researcher 


\section{The non-formal education network creates bridges to thenew society}

Inclusion should not be reduced to simply being part of the job market; it also involves establishing security and trust in society during a transition to a new country and the introduction to its culture. Having a job and being able to support oneself is central, but is not enough. One important element of non-formal education is its building of networks in a society. Non-formal education also acts as a hub in civil society organizations. Participants in non-formal education can access various social contact areas and networks. Becoming a part of a network naturally creates inclusion. We also know that networks increase the chance of getting a job. As a newcomer there is a big difference between only meeting public employees, and participating in non-formal education and getting involved in society's many different networks

Openness for different opinions and individual solutions is beneficial when meeting newly arrived immigrants. It goes without saying that a meeting between Nordic cultural views and the views from a newcomer's country of origin can create tensions that need overcoming.

\footnotetext{
"Several programs have an explicit aim of providing a social network."

Sissel Kondrup, researcher

"All of the examples create opportunity-room for building social networks. Given that social capital consists of trust, social norms and shared values characterized by reciprocity and commitment for common goods, these examples for sure promote confidence, trust and common values."
}

Jorun Stenøien \& Christin Tønseth, researcher

\section{Build the activities from the ground up to broaden participation}

There is a need to actively reach out to newly arrived immigrants who may be far from the job market. It is not enough to reach out to only those who actively seek help. In this area the administrative authorities often don't succeed fully. It is the experience of nonformal education that successful activities must be built from the ground up based on existing needs and by people who know the target group well. Working from that principle, the road leading to employment and society is faster. Through the non-formal education approach - to meet people as they are - people with weak social networks or 
disabilities also get the chance to increase their quality of life, even if they remain far from the job market. This way, we meet people where they are and as they are.

Through validation, newly arrived immigrants' unique knowledge, skills and abilities can be valued and applied, making the transition to work-life smoother. A shared perspective is to both enhance self-esteem and expand opportunities by putting forth skills and qualifications to employers, intern hosts or educational institutions. Nonformal education always begins from the individual's current situation and adapts methods accordingly, unlike formal education institutions, municipalities and employment services that function based on curricula, laws and regulations.

"The most important understanding is that initiatives of this kind should not come from the outside
or, so to say, top-down. The people from our side who participated in the project all had relatively
extensive experience with Swedish civil society organizations whilst also having good knowledge of
the other participants' various ethnic and religious backgrounds." Ibn Rushd, Sweden

"The coaches have been an important player in this project. They have immigrant backgrounds and feel integrated in their second country. The coaches have served as a positive model for newly arrived immigrants."

Fatima, NBV, Sweden

\section{Conscious gender equality perspective gives results}

The message of non-formal education is clear: there is a need for an agreed gender equality perspective in all activities. Awareness is required in form and content in order to get a great deal of female participation and equal education. Non-formal education can create the safe space needed to meet the challenges of many women with young children, who in many cases have to live up to patriarchal expectations about the role of women in the home. A possible solution may be creating activities tailored for female participants. When non-formal education applies well-thought-out strategies for gender equality, women have successfully been included in activities.

It is also important to have a long-term perspective on the work with gender equality, where both men and women are included. In order for both men and women to be included in a new society, the long-term aim must be that they both participate together in joint activities. Both genders need to be part of the dialogue on how this vision can be transformed into reality. 
The Nordic countries have a uniquely high proportion of women in the workforce. This is an important value that requires deliberate efforts, as this ethic often looks quite different in other parts of the world where many of the newly arrived immigrants come from.

"Because the evening school was not a government agency, and because the women felt it was a safe place, they dared to meet up and participate in the project. For many of them it became their entry into Danish society - and to increased self-esteem, better language skills and a larger network, also among ethnic Danish women."

Genbrugsdesign - DOF Allerød Fritidsskole Allerød, Denmark

"A few more women than men belong to our groups, which contributed to the decision to create a separate group for women only in 2001-2002. The main objective of this activity was to strengthen the role of immigrant women in society through many discussions on women's rights, gender equality, child education, as well as a major focus on health and well being."

Substral, Studieförbundet Vuxenskolan, Sweden

"Through public education, women learn to take care of themselves, gain new knowledge, build a network, and to participate in society. In short, they get increased well-being, inclusion and integration into society."

Shahrazad - Dansk Oplysningsforbund Copenhagen, Denmark

"The special thing about this project is that babysitting can be arranged at the very place the course is held in order to provide equal opportunities for both women and men to attend the courses."

Borgå National Institute

"Separating the genders in classes often resulted in better discussion."

Simey Nordic Project, Iceland

\section{Genuine inclusion is based on lifelong learning}

Free non-formal education shows opportunities to develop continuous personal pathways for newly arrived immigrants for personal learning and transitioning to work life. Early and lasting education is key for successful inclusion and the prevention of marginalization. Non-formal education's view on knowledge is open and inclusive.

Non-formal education has a long tradition of working with education and culture. We have a well-developed pedagogy with active participants and extensive 
experience in educating those who have considerable shortcomings in their previous education. This advantage gives non-formal education a good opportunity to quickly create activities aimed at new groups such as newly arrived immigrants.

\footnotetext{
"The project is a good example of the opportunities non-formal education has in developing prolonged personal study paths for immigrants, ranging from continuing education to transitioning to work life. The early and uninterrupted implementation of integration programs has a major impact on the success of the resulting integration and in the prevention of marginalization."
}

Finland Vastaus SKY

\section{Inclusion must be a long term and sustainable effort}

Successful inclusion through independent structures such as non-formal education must be long term both in relation to the participants and the organizations involved. Time-limited projects that are not continued risk being unable to provide long-term results and putting participants in a tight spot. To make good activities permanent, a follow up plan needs to be in place when a successful project ends.

Considering its resources non-formal education operates at a low cost and with good results. Unlike public agencies and private education, non-formal education combines paid staff with non-profit organizations, offering significant benefits.

However, quality operations cost money and need financing. In order for nonformal education to be able to make a truly significant contribution to the inclusion of newly arrived immigrants into society, it depends upon reasonable funding.

\footnotetext{
"The centre is run by three employees, one trainee and 170 volunteers. It is important to have a vision and a good framework, as well as to trust and cooperate with the volunteer leaders of the centre; Give them the opportunity and knowledge to lead on in their own way. Find a good balance between the volunteer leaders' independence and the organization's support and responsibility."
} 


\title{
10. Making people's skills visible - validation
}

Non-formal education is familiar with linking the efforts of newly arrived immigrants to the needs of the job market. Within its large networks, there is regular contact and cooperation with local employers and with the job market's needs. Assessing and adapting existing skills according to need is done through validation. Through various forms of validation, newcomers' knowledge, skills and abilities can be valued and made use of, making social and work life easier. The common perspective is to both strengthen self-esteem and increase opportunities where skills and previous experience can be described for employers, interns, and educational institutions or in other contexts. Non-formal education is always based on the individual's current situation and adapts methods accordingly, unlike formal education institutions, municipalities and employment services based on curricula, laws and regulations. Non-formal education always aims at describing the skills of the person as a whole.

\begin{abstract}
Assessing capabilities and knowledge is included in practically all activity examples. You can choose to formulate it differently, as it is often about strengthening self-esteem and having the opportunity to show what you can.
\end{abstract}

\section{Comment from one of the researchers}

In recent years, non-formal education has played an increasingly vital role in contributing to the inclusion of newly arrived immigrants in Swedish society. We in Sweden have seen this in relation to, among other things, assignments directed to offer asylum seekers "Swedish from day one and community introduction".

In the last 2 years, non-formal education in Sweden has successfully managed to reach a majority of asylum seekers. The image that non-formal education conveys, through its own evaluations and statements, is that this activity is valuable and successful. However, as this is a relatively new phenomenon, there is no research that

\footnotetext{
${ }^{1}$ Swedish from day one is a program aimed at giving Sweden's newly arrived immigrants the opportunity to learn Swedish early on, while simultaneously gaining a basic understanding of Swedish society. An important purpose is to provide participants with a meaningful activity during the asylum process.
} 
can confirm or challenge this self-image. Neither do we know whether these types of activities have a more long-term impact on the inclusion of immigrants in society.

In other words, there is a huge need for research on the role of non-formal education in contributing to the broader inclusion of immigrants. There is also a need for research that can offer more specific information about how non-formal education contributes to the longer-term inclusion of immigrants especially in moments of unusually extensive immigration and through efforts such as the learning the Swedish language from day one and community introduction. In this way, knowledge made available can support the development of these efforts and contribute in making the future inclusion of immigrants even better.

\section{Andreas Fejes}

Researcher and project participant

\section{Researchers: Foster self-initiative and mindful meetings}

Below, two texts and one interview with David Samuelsson, by journalist Anna Morin, who attended the conference in Jönköping. The articles have been published on the website of Studieförbunden.

What can the Nordic non-formal education offer newly arrived adult immigrants? Which models work towards their establishment in society and working life?

These were the questions of the day when the Studieförbunden and its sister organizations in the Nordic countries gathered at a conference in Jönköping. Scientists and public educators put their heads together during various lectures and discussions. The answers came down to: creating a dialogue, emphasizing mutuality and fostering self-initiative, all while putting focus on research for non-formal education.

Before the conference day, 22 selected examples of activities for newly arrived immigrants had been collected from Sweden, Iceland, Norway, Denmark and Finland. Included was everything from playing in a marching band to going for a walk and doing handicrafts, to visiting potential workplaces. 
"It is important for participants to do something they already feel a connection to in order to understand who they are in this new context", says Eva-Marie Harlin from Linköping University.

As one of the seven academics who read and reflected over the examples from her perspective and research, Eva-Marie Harlin is also a program manager and teacher at the Folk High School Teacher Programme. She referred to Gert Biesta's theory that education can have three purposes: provide practical skills, teach social skills, or develop as an individual.

"The best thing would be if we could find a model that worked on all three levels at the same time."

Trine Bendix is the Secretary-General of Dansk Folkeoplysning Samråd, the largest public non-formal education organization in Denmark. She remarked that, in many cases, those three levels already interact in the context of non-formal education, such as when someone's interests in handicrafts causes them to experience and learn completely different things.

"You can learn something completely different than what you planned. I have an example from Denmark where refugee women are participating in recycling design. While they are doing this, they can talk about a letter they received, making everyone both help translate and then discuss the content. The activity becomes more than the craft, it also becomes an opportunity to talk about society, relationships, roles in their family and other things", Trine Bendix explained.

At the Norwegian University of Science and Technology (NTNU), two researchers are working on a joint analysis of the non-formal education examples. Jorun Stenöien, Professor of adult education, and Christin Tönseth highlighted that there is a space for possibility, opportunity room, where on one hand the individual's needs, interests, cultural values and experiences, and on the other, the different structures from the external culture, can meet and develop. Getting to the place in between can happen in different ways, and then the leader's role and the participants' entryways are crucial.

"Learning is about attitudes to life. Either you wait for the language course to start and learn nothing else, or start on your own and seek knowledge and practice speaking the language", says Christin Tönseth.

Both when seeking knowledge and when educating oneself, motivation is a crucial driving force. Thus, prioritizing self-help and encouraging self-initiative is an 
approach within non-formal education that is a success factor. It can also be about valuing experiences that can serve as a common ground.

"I think we must have leaders and organizers who themselves are immigrants. It is part of improving public education", commented Trine Bendix.

Karin Ekermann coordinates the activities of asylum seekers at the national level at Studiefrämjandet. In the Swedish Studieförbunden, she participates in a group together with others who have the same function at the other nine study associations. She attended the conference and was able to contribute a grassroots perspective. Karin Ekerman could report that many departments at Studiefrämjandet have initiated major activities with asylum seekers over the past two years. Together, in dialogue with Karin over the phone and at physical meetings with people from all over the country, they exchange experiences and methods on the study program's intranet.

"We got funding for the Swedish from day one initiative and could start a number of activities. If a large housing space for asylum seekers open in a municipality, then the local Studiefrämjandet often wants to contribute, and they call me".

Figure 4: Karin Ekermann

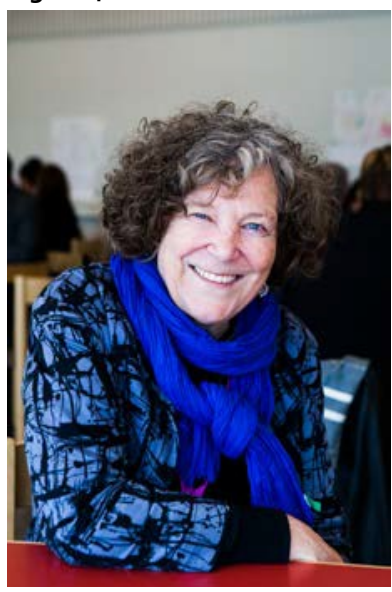

Karin pointed out how associations can gather established citizens and newly arrived immigrants together around one mutual interest, and hopes that there will also be an effort made for those who received asylum in Sweden. 
"We are already working with asylum seekers and many of them turn to a study association when they have been granted a residence permit. We can offer education and a first step into society through different community contacts as newly arrived immigrants have different interests", says Karin Ekermann.

Several of the researchers emphasized the difference between education in order to make the student fit into current society, and education that emphasizes relationships, friendships and shared interests among the adult participants.

One whose reasoning was in the same spirit was Inaluk Brandt, CEO of FoCus in Greenland, and part of NVL's network. She was invited to the conference as a corporate representative and demonstrated that methods similar to the ones applied by non-formal education and study associations have worked well. "There is a general method that promotes inclusion, which I have tried. It can be as simple as asking newcomers where they are in their lives right now and what they need. We start there. It's a kind of action-learning", says Inaluk Brandt.

Figure 5: Inaluk Brandt

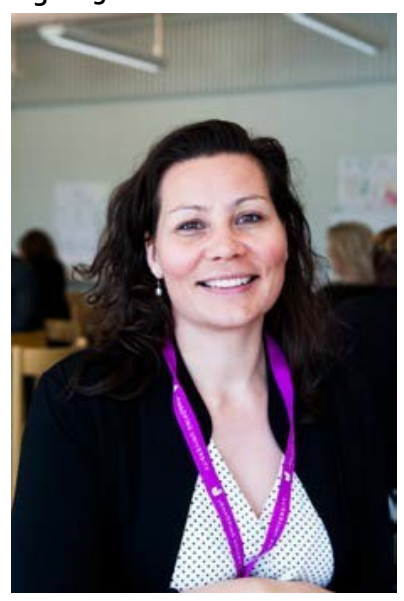

She has worked with development in the public sector and private companies in Greenland, and believes that good results come from training the entire work group who takes in a new employee and colleague. If the group is well prepared, also other qualifications than expected can become an asset in work-life. 
"It is possible to hire someone with less experience if the group is prepared to welcome them into the team. Even if the individual may lack something, it is still possible to focus on what the person can actually contribute instead of what he or she can't. That way, the group can accept it."

The academics at the day-long conference came from different countries and universities: NTNU in Norway, Åbo Academy in Finland, Roskilde University in Denmark and Linköping University in Sweden. Other participants came from other universities in Sweden and Europe, and from northern non-formal education organizations such as Studieförbunden and in a few cases, from groups set up for newcomers. Studieförbunden arranged three events: a research symposium, a lecture with entrepreneurs, and a workshop on the best methods for the learning and establishment of adults. More than 100 people participated in the conference.

The project leader for the Studieförbunden program at the NCAEL was Kajsa Wiktorin. She was pleased with the event and expressed how she gained new insights about how non-formal education supports newcomers to easier settle in a country.

"It was interesting to get a closer look at the researchers' perspectives on activities created for newly arrived immigrants in the Nordic countries. In a Europe and in a world - where people migrate for a variety of reasons, it is important that people get the chance to meet their new country in their own way."

"During our part of the program, people with direct experience of fleeing, relocating and going through challenges in a new country participated.

Personally, I was pleased with the clear stand against xenophobia that I found both amongst researchers and those who work more hands-on".

Kajsa Wiktorin concluded that the conference succeeded in becoming an arena where people with different unique knowledge and experience could meet. "Formal education, which was also discussed at the conference, is looking for much of what non-formal education offers: a context where all people get the chance to take their space and express themselves." 


\section{Research on establishment in progress}

The full day with researchers and public educators was part of the Nordic Conference NCAEL, the Nordic Conference on Adult Education and Learning. This year, NCAEL was held at the University of Education and Communication at Jönköping University, where the National competence centre for lifelong learning, Encell, is located. Cecilia Bjursell is the head of Encell and was very pleased with the conference days and the meeting between theorists and practitioners. She emphasizes the importance of continued research.

"Lifelong learning will play an increasingly important role as a result of on-going societal changes, and there is a great need for research in this area in order to develop knowledge and methods that promote adult learning. This research would benefit in cooperation with adult education associations."

Andreas Fejes is a professor of adult pedagogy at Linköping University. At the conference, he stated that ABF (The Workers' Educational Association) has contributed funds for studies of Swedish from day one, non-formal education for asylum seekers, and plans to further research immigration, education and social inclusion, focusing on folk high school courses and SFI, Swedish for Immigrants. Andreas Fejes thinks there is too little research on non-formal education's work with language learning and that there are no studies on how immigrants themselves look at the long-term effects of language learning. Cecilia Bjursell agrees that research on adult education must be prioritized even more.

"Non-formal education in the broadest sense is largely a non-profit effort, and today, adult education is not a priority with research funding agencies", says Cecilia Bjursell. 


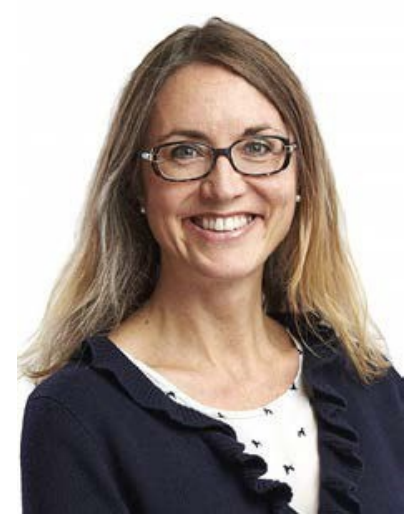

"Funding is required for college students to be able to devote part of their working time to non-formal education, regardless of whether it concerns research, education or knowledge dissemination."

Karin Ekermann from Studiefrämjandet also wants to see more research: "I think it would be great to see the effects of everything we do. In our daily work we have our hands full and would like to know more about the long term effects."

\section{Interview with David Samuelsson - New meetings and Nordic perspectives on establishment}

The day after the one-day-long program I meet a satisfied David Samuelsson, Secretary-General of Studieförbunden. At Jönköping University, the longer conference on adult learning (NCAEL) is still proceeding, and the final lecturer, Anna Ekström, Minister for Upper Secondary School and Adult Education and Training, has just entered the building. Meanwhile, David Samuelsson meets with his Nordic counterparts, the Secretary-Generals of non-formal education organizations.

"The issue of the inclusion of newly arrived immigrants is big in all of the Nordic countries", says David. "I am convinced that non-formal education should be a part of it." 
Do you have any concrete examples of what your exchange of experiences has offered?

"In the non-formal education sector we have a lot to learn from each other. We can see that in Finland, folk high schools and study associations play an important role in the integration phase. I think that Sweden could learn from this."

"In Denmark, they are good at citizen education. It is about having a dialogue and non-formal education for all members of society. Today there are many who spread intolerance and fear and we must work to form a society that can handle large number of migrants. That has become clearer to me", says David Samuelsson.

Figure 7: David Samuelsson

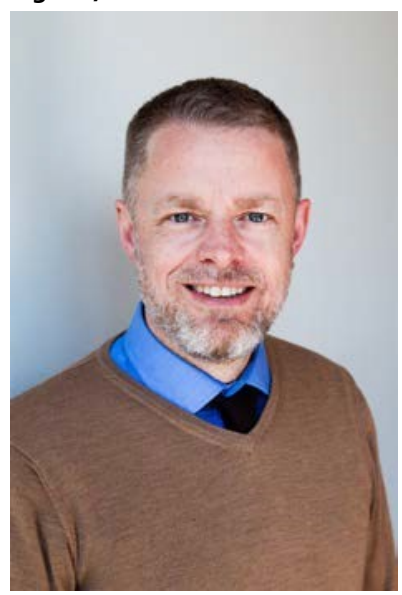

A research conference with non-formal educators, did it work well? "Having researchers from five countries was a success! It created many new meetings and provided good perspectives. We need the stimulus that researchers provide. They are outside experts who come with various perspectives and drive our businesses to take the next step."

"Within non formal education we are very good at the hands on work, but we also need to have theorists and have to work with well-thought-out models and methods," David Samuelsson concludes. 



\section{Sammanfattning}

\section{Inkludering av nyanlända genom det icke-formella lärandet - Nordiska goda exempel}

Lärdomarna av projektet med en genomgång av tjugotvå verksamhetsexempel har visat att den nordiska folkbildningens helhetssyn på människan skapar stora möjligheter för lyckad inkludering av nyanlända. Människor från olika delar av världen bosätter sig i de nordiska länderna och för att de ska känna sig välkomna, kunna visa sin hela kompetens och mötas som de människor de är krävs ett bemötande som skapar trygghet och förutsättningar för delaktighet. Det formella lärandet passar vissa, men för andra krävs öppnare pedagogiska former där olika kompetenser kan utvecklas och tillvaratas. Det icke-formella lärandet kan äga rum i en förening, på en språkkurs, i yrkeslivsintroduktion eller till och med i naturen. Flera av de medverkande forskarna talar om s. k opportunity rooms, rum och sammanhang för möten och utveckling där människors förmågor kan tillvaratas, också sådan kunskap det saknas betyg eller intyg på. Såväl analfabeter, unga utan gymnasiekompetens som välutbildade kan, genom att slussas via folkbildningen, hitta in i samhället, bli aktiva medborgare och del av arbetslivet. Folkbildningen kan finnas med redan från start, när en människa precis kommit till ett nytt land, när det är dags för etablering och sedan i fortsatt utveckling under livets alla faser. 
De tio slutsatserna som projektet och konferensen kom fram till ska användas som utgångspunkt för diskussioner och utveckling av modeller för nyanlända. Vad krävs för att nyanlända ska bli en del av ett nytt samhälle och dess arbetsliv.

1. Delaktighet skapar förutsättningar för inkludering.

2. Hela människor måste inkluderas.

3. Det flexibla icke-formella lärandet kan möta skiftande behov.

4. Språket banar vägen till anställning, kultur och samhälle.

5. Med det icke-formella lärandets, folkbildningens, nätverk skapas broar till det nya samhället.

6. Aktiviteter som möter verkliga behov - både från de nyanlända och från samhället - ökar delaktigheten.

7. Medvetet jämställdhetsperspektiv ger resultat.

8. Hållbar inkludering bygger på livslångt lärande - rätten att få lära sig under hela livet.

9. Inkludering måste vara ett långsiktigt och hållbart arbete.

10. Synliggör människors färdigheter genom validering. 


\section{Appendix 1. Participating researchers in the project}

\section{Eva-Marie Harlin}

Ph.D. as well as program manager and pedagogue at the Folk High School Teacher Programme at Linköping University. She also works with the development of competence of active folk high school teachers and school leaders. In addition to this she works with assignment training and further training days for the folk high school and is the course coordinator for the course Folkhögskolan's idea and pedagogy, which addresses the folk high school pedagogues. She is also in the research environment for adult pedagogy and education. Member of the MIMER Council.

\section{Henrik Nordvall}

Lecturer in Education at Linköping University and Mimer's manager. Contact person at Mimer for the project People's education and adult education sector's role in integration and employment efforts in the Nordic region

\section{Annika Pastuhov}

Post-graduate in adult pedagogy at Åbo Akademi, Vasa, Finland. Specialized in nonformal education and civic educational processes. Expected to present her doctoral thesis in 2018. Speaks both Finnish and Swedish and is knowledgeable about the Nordic non-formal education context. She is well acquainted with the ideas behind the project and contributed with valuable comments in the process of making the form that was used to collect data and information 


\section{Sissel Kondrup}

Ph.D. and adviser at Uddannelses forbundet, Copenhagen, Denmark. In 2012, at Roskilde Universitet, she defended her thesis "Livslang læring for alle? En arbejdslivshistorisk undersøgelse af det ufaglærte arbejdsliv som betingelse for livslang læring og opkvalividering." She is specialized in the work life related dimension of adult learning and education that is vital for the project.

\section{Jorun M. Stenøien}

Professor at Institutt for pedagogikk og livslang læring, NTNU, Trondheim, Norway. Dr. rer. pol. (Doctor rerum politicarum) in sociology and has for 20 years had adult education as a research and work field. Has been focusing on learning processes and forms in different thematic contexts and arenas of society. The work has mainly dealt with education and learning at the "University of Life", i.e. research in non-formal education, learning and knowledge that arises through participation, cooperation and fellowship. The activity is here described in the form of four problem areas that are often overlapping: 1) Citizenship, participating and contributing, 2) Social change and learning, 3) Practical knowledge, and 4) Interest-based learning.

\section{Andreas Fejes}

Professor in adult learning at Linköpings Universitet. Extensive research in adult education, non formal education, validation, citizenship and learning in work life. Has developed a major research program concerning migration, learning and social inclusion. 


\title{
Appendix 2. Participating projects in the study
}

\author{
\begin{tabular}{l|l} 
Institution & Target group
\end{tabular} \\ Danmark \\ Fokus flexpraktik \\ Arbetssökandenyanlända \\ Daghøjskoleforeningen \\ Aalborg \\ (newly arrived, job seekers) \\ Genbrugsdesign \\ Flyktingkvinnor (med svag integrering) \\ DOF Allerød \\ (newly arrived women, weak integration) \\ Fritidsskole \\ Shahrazad \\ Flyktingkvinnor (lite äldre) \\ Dansk Oplysningsforbund \\ (Immigrant women, eldery) \\ Silkeborg \\ Silkeborg højskole \\ 18-21 år utanför arbetsmarknaden \\ (Young people, age 18-21 without work) \\ Kursustrappen \\ Nyanlända \\ Frederiksberg \\ (Newly arrived) \\ Daghøgskole og kursuscenter
}

Finland

Kombi

Borgå Medborgarinstitut

SFX Svenska

Helsingfors Arbis

Kitee

Kiteen evankelinen kansanopisto

Nyanlända med uppehållstillstånd

(Newly arrived with residence permit)

Personer med a2 (eur. färdigshetsskalan)

(People with A2 Europeen scale)

Ungdomar utanför arbetsmarknaden

(Youngsters outside the labour market)

Det fria bildningsarbetets

Integration börjar (minderåriga asylsökande) med tidig utbildning

(Young jobseekers)

2o Folkhögskolor

Ossi/skills up

Arbetslösa under 30 med invandrarbakgrund

Lahtis folkhögskola

(Unemployed belovezo) 


\section{Norge}

Norgeema

Norska turistföreningen

FU - projekt 7

Folkeuniversitet

Gränslösa grönsaker

Det norske hagelselskap

Vinterpuls

NMF

Stella röda korset kvinnecenter

Oslo

Island

Mimir

Reykavik lifelong learning center

Simey

Lifelong learing center in Akureyr

\section{Sverige}

Ett jämställt föreningsliv ibn rushd

Fatimaprojektet

nbv

Substral

sv

Påfart

västerås fhs

Medborgarskolan

Nordmaling anställbarhet
Ungdomar 14-19 år

(Youngsters 14-19)

Hälsopersonal med ursprung utanförEØS-området

(People with training in the field ofhealth)

Kvinnor och deras familjer

(Woman and their families)

Barn samt kompetenshöjning för personal

(Children and skills for the staff)

Kvinnor

(women)

Syrianska flyktingar

(Syrian newcomers)

Syrianska flyktingar

(Syrian newcomers)

styrelseledamöter inom medlemsorganisationer (fokus kvinnor)

(women in compounds)

Invandrarföreningar som arbetar mot hedersrelaterat våld

(Immigrant associations working against honor violence)

Långtidsarbetslösa med invandrarbakgrund

(Long term enployed with immigrantbackground)

Inskrivna påarbetsförmedlingen, etableringsuppdraget

(Jobseekers)

Nyanlända från krigsdrabbade områden som behöver lära sig svenska förökad (Swedish for newly arrived from war affected areas) 


\section{Attachments}

- The conference program

- All participating examples

- The printable folder with the conclusions for further dissemination 


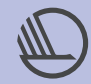

\author{
Nordic Council of Ministers \\ Nordens Hus \\ Ved Stranden 18 \\ DK-1061 Copenhagen \\ www.norden.org
}

INCLUSION OF REFUGEES THROUGH NON-FORMAL EDUCATION 2017

This project, based on a research study of good cases on inclusion from the Nordic countries, tries to answer the question: What is required for new arrivals to become part of a new society and working life?

The result was presented during a one day program at the NCAEL 7th Nordic Conference on Adult Education and Learning, 3-5 May 2017 in Jönköping in Sweden, where researcher, experts and practitioners from the Nordic countries discussed and formulated ten conclusions of best models for inclusion.

This report describes all parts of the project. The research, the cases, the content of the conference and the ten conclusions on good inclusion based on Nordic activates as well as documents for disseminating, to start discussions and increase the knowledge about models for inclusion of new arrivals. 